\title{
Nanogel and its Utilization in Cosmeceuticals
}

\author{
Manisha Sharma, Brijesh Ojha, Azmi Khan, Madhu Gupta* \\ Department Of Pharmaceutics, Delhi Pharmaceutical Sciences and Research University, \\ PushpVihar Sec- 3, New Delhi
}

\begin{abstract}
In global market the demand for cosmeceuticals have shown an appreciable amount of enhancement over the past few years, especially the novel technology is more explored by the researchers as well as the marketers. Nanotechnology provides a wide platform for innovation and variation, the nanocosmeceuticals have shown an amplifiable amount of growth. Nanocosmeceuticals such as nanogels, nanoemulsions, liposomes, niosomes, solid lipid nanoparticles etc. have been used widely due to targeted delivery of the active ingredient, modification in shape, size, colour, penetration into the skin, controlled release delivery of the actives and much more. In global market there are a lot many Nanocosmeceuticals based products exist. Especially, Nanogels are three dimensional polymer network systems and they provides favorable characteristics to formulate, incorporate \& fabricate hydrophilic as well as hydrophobic formulations which are required in many cosmeceuticals products. Nanogels can easily replace the conventional cosmeceuticals due to substantial amount of benefit which it provide such as their stimuli responsive behavior, $\mathrm{pH}$ responsive mechanism of drug release, small particle size, high water imbibing capacity, tremendous bio compatibility. The various applications of the nanogels in cosmeceuticals has been discussed in this review along with the general properties of the nanogel.
\end{abstract}

Keywords: Nanogel, Nanocosmeceuticals, Nanotechnology, Global Market 


\section{INTRODUCTION}

The cosmetic market globally is that sector which is unaffected to the routine loss and profit, the main reason for this abundant growth is the usage and everlasting demands of cosmetics by women as well as men because they do want to look more appealing and youthful. The global cosmetic products market was valued at USD 532.43 billion in 2017, and is expected to reach a market value of USD 805.61 billion by 2023, registering a CAGR of $7.14 \%$ during 20182023. The growth of cosmetic market graph has shown a shift towards Asia-Pacific from UK, USA, Germany in the last few years due to the stabilization in these developed markets. The countries like India, China they provide a promising platform for the cosmetic industries because they have enormous youth population and these population is well educated and aware about cosmeceutical product which are present globally few of them are anti aging, face oils, hair serums etc. The major resistance in these countries is cost because people over there prefer affordable cosmetics formulations rather than the niche segment, so manufacturers have to think upon this, so that they become capable of catering their products to large masses in these countries. Apart from pricing the suppliers and manufacturers have to focus on skin care cosmeceuticals because this area has received major growth over the last few years.

The Graph 1 represents the various segments of the cosmetic market globally from 2011 to 2018. In this it is clearly depicted that the skin care products accounts for more than $39 \%$ of the global cosmetic market.

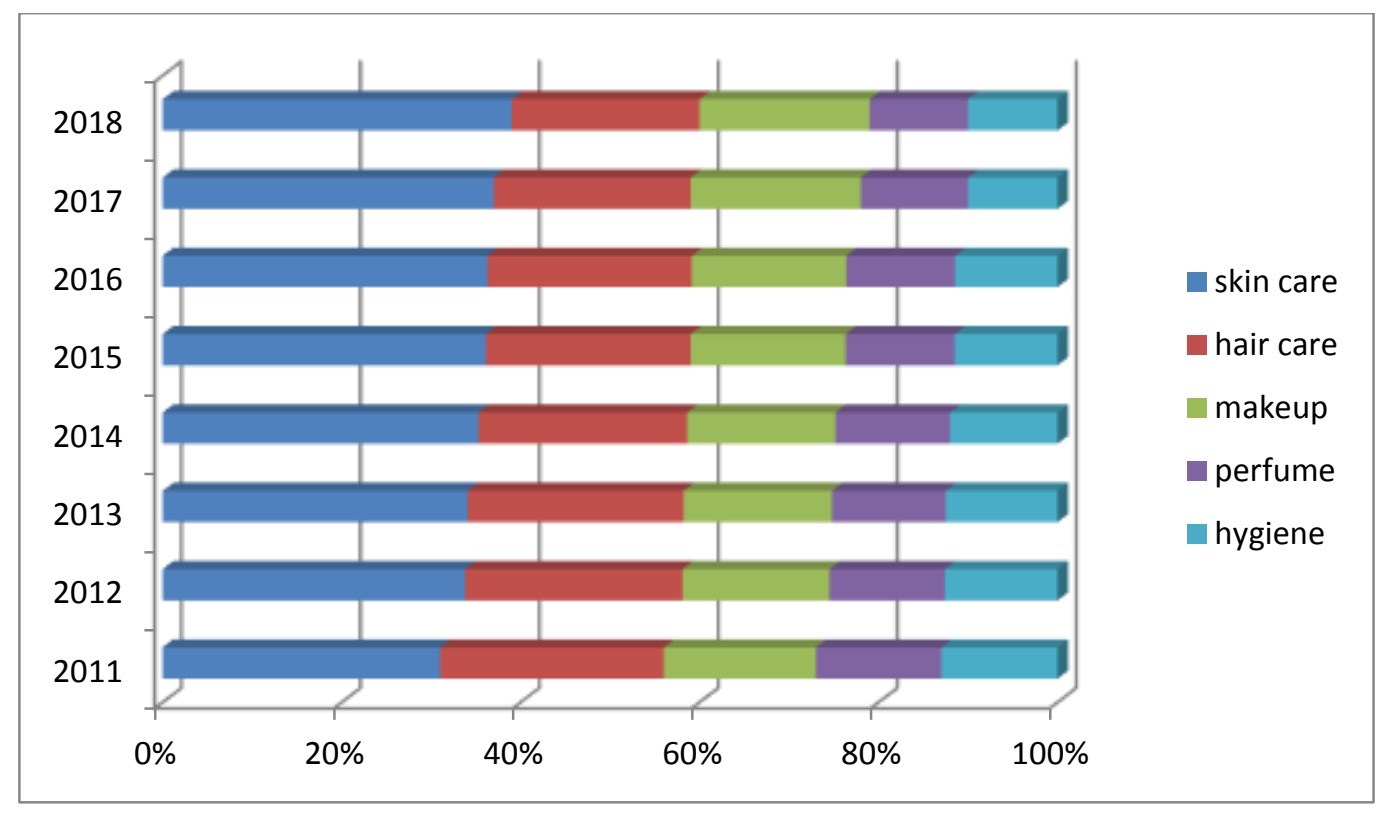

Graph 1: Various segments of the cosmetic market 
India Cosmetics market is projected to grow at a CAGR of over 6\% during 2019-2024 (1). Some of the major players operating in the India cosmetics market are REVLON, Amway, Chanel, CIATÉ, Kao, Estée Lauder, LVMH, Mary Kay, Natura, Oriflame Cosmetics, Procter \& Gamble, and Unilever etc.

In today's world it becomes essential to maintain the enthusiastic and healthy expression in front of others. In India more than 560 million people are in the age group of 18-35 years with growing number of youth population the urgency for looking representable enhances and which in turn increases the cosmetic market. This growth will become double with an increasing number of working women force in India, they desire to maintain the beauty and elegancy, hence the growth of the personal care cosmeceuticals industry boost up (2).

From various surveys conducted by autonomous bodies it has been clear that all the leading cosmetic manufacturing companies are using nanotechnology to formulate novel products. Few of them such as Estee Lauder jumped into the nanocosmetics way back in 2006 with a wide range of products containing "nanoparticles". One of the largest cosmetic company in the world 'L'Oreal" has been ranked 6 in nanotech patent holder in US, it spends $\$ 600$ million dollars of its $\$ 17$ billion dollars wealth in generating nano patent and they have generated many patents on the use of nanosome particles. Other companies include color science, doctor's dermatologic formula(DDF), Freeze24/7 and many more.(1).

An estimation of how the top 10 cosmetic companies of the world rank in terms of nano-related patents, based on Espacenet database, is depicted in Graph 2. (1).

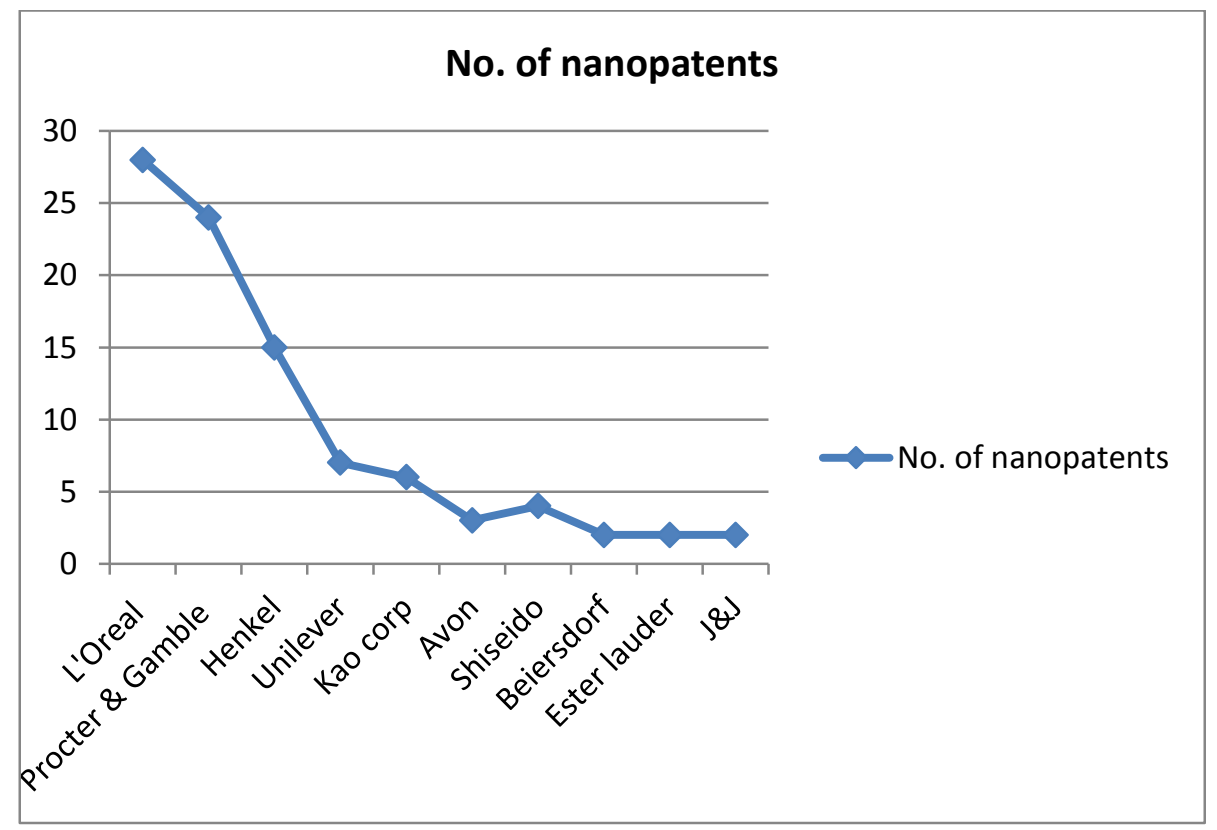

Graph 2: Nano-related patents, based on Espacenet database 
Nanotechnology has found its utilization in various commercial products. In 2009, more than $13 \%$ of the total one thousand nanotechnology based products were classified as cosmetic products. This domination of nanocosmetics is due to their enhanced properties like color, transparency, texture, increased shelf-life, etc(3)(1).

Nanotechnology, a relatively novel technique, offers a broad scope for a smart drug delivery approach involving the design, synthesis and characterization of molecules and devices that have effective function at nanometer scale.

Some of the nanotechnology-based innovations are nanoemulsions, nanogels, nanocapsules, nanopigments, liposomes, niosomes, nanocrystals, solid lipid nanoparticles, carbon nanotubes, fullerenes, and dendrimers(4).

Nanogels are hydrogel material which are in the nanoscale size range having a three dimensional structure. Nanogels are synthesized by crosslinking of the polymer network which have a high capacity to retain water into it and they also have a unique property of itself not dissolving into the aqueous phase.(5)

In this review the discussion is focused on the marketed formulations which are available as nanocosmeceuticals, various aspects of nanogel like its characteristics, techniques of synthesis, as well as various domains in which the nanogel technology can be applied is also discussed.

Particular attention is dedicated on the application of nanogel in cosmeceuticals because in the developing world women as well as men both are much concerned about their physical appearance as well as protection from UV radiation, age spots removal, hyperpigmentation etc. also the nanogel can be applied for the delivery of drug in inflammatory disorders such as psoriasis .

\section{Available Nanocosmeceuticals in market}

With emerging trend of Nanocosmeceuticals based products the cosmetic market is having numerous products which cater the needs of the consumers with enhanced and additional benefits of nanotechnology. In global cosmeceuticals market there are over more than hundreds of researchers \& manufacturers who emphasized research on nanotechnology based products . 
Table 1: It depicts various Nanocosmeceuticals based products in market

\begin{tabular}{|c|c|c|c|c|}
\hline S.no & Nanocosmeceutical Product & Usage & Manufacturer & Benefits \\
\hline 1 & $\begin{array}{l}\text { Hydra flash bronzer daily face } \\
\text { moisturizer }\end{array}$ & Moisturizer & Lancome & $\begin{array}{l}\text { It provides antioxidant protection and make skin healthy } \\
\text { \& glowing naturally }\end{array}$ \\
\hline 2 & Hydrazen cream & Moisturizer & Lancome & $\begin{array}{l}\text { It contains nanoencapsulated triceramides and provides } \\
\text { softness, hydration to the skin }\end{array}$ \\
\hline 3 & $\begin{array}{l}\text { Nano hand and nail moisturizing } \\
\text { serum and foot moisturizing serum }\end{array}$ & Moisturizer & $\begin{array}{l}\text { Nano infinity } \\
\text { Nanotech }\end{array}$ & $\begin{array}{l}\text { Zinc oxide nanoparticles prevents drying and hurting of } \\
\text { hands, nails and feet }\end{array}$ \\
\hline 4 & Lancomerenergiemicrolift & Antierinkle & Lancome & $\begin{array}{l}\text { It contains colloidal silica and soy protein nanoparticles } \\
\text { to provide face lift affect }\end{array}$ \\
\hline 5 & $\begin{array}{l}\text { Revitaliftanti wrinkle, firming face, } \\
\text { neck contour cream }\end{array}$ & Antiwrinkle & Loreal & $\begin{array}{l}\text { It is enriched with pro retinol A those are encapsulated in } \\
\text { nanosomes }\end{array}$ \\
\hline 6 & Eye tender & Anti wrinkle & Kara vita & $\begin{array}{l}\text { It contains nanospheres and delivers wrinkle reducing } \\
\text { peptide to stimulate fibroblast, build collagen, brighten } \\
\text { skin and make skin look healthy }\end{array}$ \\
\hline 7 & Eye contour nanolift & $\begin{array}{l}\text { Antiwrinkle and } \\
\text { antiaging }\end{array}$ & Euoko & $\begin{array}{l}\text { It contains nanocapsules to remove fine lines, wrinkles } \\
\text { and inflammation }\end{array}$ \\
\hline 8 & Nano gold firming treatment & Antiaging & Chantercaille & $\begin{array}{l}\text { Small nanoparticles of pure gold bind to silk microfibers } \\
\text { to firm and tone skin, causing anti-inflammatory, healing } \\
\text { and antiaging effect }\end{array}$ \\
\hline 9 & Nanosphere plus & Antiaging & Dermaswiss & $\begin{array}{l}\text { It contains stem cells antiagingnanosphere to preserve } \\
\text { and protect skin cells }\end{array}$ \\
\hline 10 & Clearly it! complexion mist & Antiacne & Kara vita & $\begin{array}{l}\text { Nanospheres tackles acne problem and balances sebum } \\
\text { production }\end{array}$ \\
\hline 11 & $\begin{array}{l}\text { Soleil soft touch anti wrinkle sun } \\
\text { cream with SPF } 15\end{array}$ & $\begin{array}{l}\text { Antiwrinkle and } \\
\text { sunscreen }\end{array}$ & Lancome & $\begin{array}{l}\text { It contains nanocapsules of vitamins to preserve skin } \\
\text { youth and create } 10 \mathrm{mg} \text { lasting effect and protect from } \\
\text { sun rays as well }\end{array}$ \\
\hline 12 & Lip tender & Lip moisturizer & Kara vita & $\begin{array}{l}\text { Ten bioactive ingredients loaded on lyphazomes cause } \\
\text { long lasting hydration for fast and dramatic lip repair }\end{array}$ \\
\hline 13 & Nanocyclic cleanser silver & Cleanser & Nano cyclic & $\begin{array}{l}\text { It is a blend of nanosilver and natural ingredients that } \\
\text { kills harmful bacteria and fungi. treats acne, exfoliates } \\
\text { dead skin, reduce age spot and wrinkles }\end{array}$ \\
\hline 14 & Nanorama-nano gold mask pack & Face mask & LEXON & It contains pure nanosized gold, highly effective in \\
\hline
\end{tabular}




\begin{tabular}{lll}
\hline Primordial optimum lip & Nanotech & $\begin{array}{l}\text { penetrating small pores and disinfecting skin, helps to } \\
\text { reduce pore size, prevents and treats acne } \\
\text { Delivers Vit. E via nanocapsules to lips to reduce } \\
\text { bleeding and feathering due to fine lines and wrinkles }\end{array}$ \\
\hline
\end{tabular}




\section{Rationale for the exigency of nanogel based cosmeceuticals}

Nanogels are preferred over other drug delivery systems due to their competence of reaching to the smallest capillary vessel as well as they can be penetrated through the tissues by paracellular or transcellular pathways also the drug loading capacity of nanogels is remarkable as compare to the other delivery systems.(3)

Nanogels have distinct properties like swelling, stimuli responsive behaviour and softness due to these properties the network of nanogel safeguard the enclosed biological molecules from in vivo deterioration and eradication as well as it also help in process of delivery to promote a controlled and prompt response at the target site.(6)(7)(8)(9)(10)(11)

Nanogels could be composed of a range of natural polymers, synthetic polymers or a consolidation thereof, chemically (covalent) crosslinked or physically crosslinked with noncovalent bonds by hydrogen bonds, electrostatic and hydrophobic interactions. The immense capacity of absorbing water is associated with the existence of hydrophilic functional groups, such as $-\mathrm{OH},-\mathrm{CONH}-,-\mathrm{CONH} 2-$ and $-\mathrm{SO} 3 \mathrm{H}$, along the macromolecular chains in the polymer structure.(12)

Nanogels aspects such as size, charge, porosity, amphiphilicity, softness, and degradability can be tweaked by adjusting the chemical composition. They are mostly spherical particles but the prevailing advancement in synthetic strategies allow for the fabrication of nanogels of different shapes. (13)(14) They can be also designed to have either a core-shell or a core-shell-corona structure, with at least one of the layers crosslinked for structural probity.

The adaptability of the nanogel structure allows for embodiment of plenty of molecules which range from inorganic nanoparticles to biomacromolecules like proteins and DNA with appropriate conversions of the materials used for their fabrication and this is done in such a manner that the gel like behaviour is not conceded. This type of functionality and firmness is difficult to procurable with other nanoparticulate systems notably the embodiment of entities with varying degree of physical characters in the same carrier.(15)(16)(17)

Nanogels can be categorized on the basis of their structure into: simple nanogels, hollow nanogels, multilayer nanogels, core-shell nanogels, and functionalized nanogels.(18)

Nanogel: brief characteristics, advantages \& drawbacks, drug release property, types and techniques for synthesis 


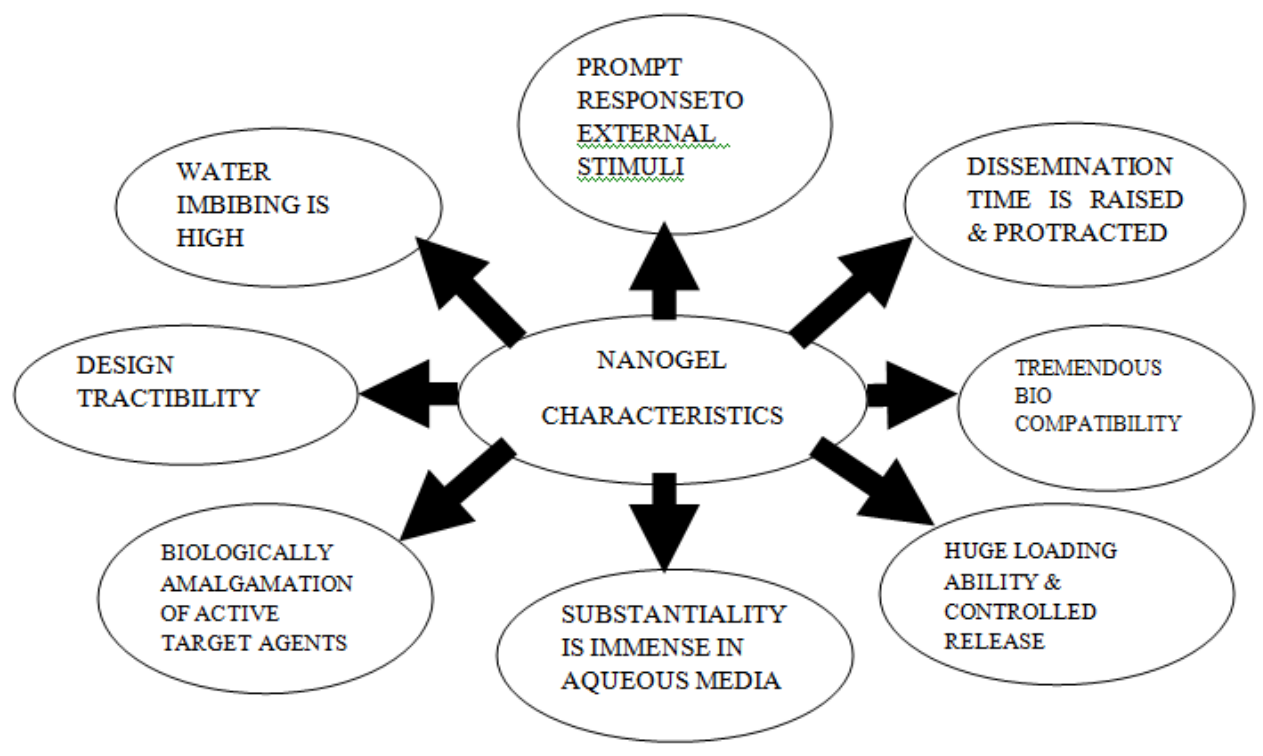

\section{Figure 1: The Multitudinal Characteristics of The Nanogel Has Been Depicted}

Table 2: Advantages \& Disadvantages of nanogel

\begin{tabular}{|c|c|}
\hline Advantages & Disadvantages \\
\hline $\begin{array}{l}\text { - Both hydrophilic and hydrophobic } \\
\text { drugs can be formulated in nanogels } \\
\text { formulation without any leakage of } \\
\text { drug from the solution(19)(20) } \\
\text { - Administration of nanogel can be } \\
\text { through various route such as } \\
\text { parenteral mucosal topical (19) } \\
\text { - Nanogels can be controlled for } \\
\text { sustained release of drug from the } \\
\text { formulation by the addition of a } \\
\text { polymeric network. Polymeric } \\
\text { networks also control the particle } \\
\text { size of the formulation (21) }\end{array}$ & $\begin{array}{l}\text { - Many a times there is a very substantial } \\
\text { interaction between drug or active agent } \\
\text { and the polymer which reduces the } \\
\text { hydrophilic nature of the nanogels, } \\
\text { causing the structure to be wrecked and } \\
\text { there will be an irreversible entrapping of } \\
\text { drug molecule.(22)(23) } \\
\text { - Restrained drug loading competency of } \\
\text { nanogels and suboptimum standardization } \\
\text { of drug discharge(24) } \\
\text { - Unpropitious effects can be seen in } \\
\text { formulation of nanogel due to the } \\
\text { presence of surface active agents or } \\
\text { monomers.(19)(25) }\end{array}$ \\
\hline
\end{tabular}

\section{Drug release property of nanogel:}

Mechanisms of drug release have been investigated based on the characteristics of the polymer systems such as temperature, $\mathrm{pH}$, and volume transition of nanogels.

Nanogels reactivity can be seen in several ways due to their responsive behaviour towards the external variables such as modifications in temperature, ionic strength, $\mathrm{pH}$, electronic and magnetic fields, light, solvent system and composition, molecule concentration, bioactive compound concentration such as glucose or other enzymes. Due to these variables nanogels can 
be remodeled in terms of their shape and dimension, dispersability, color, conductivity, light transmitting abilities, ability to get wet and various surface characteristics. (26)(27)(28)(29)(30) In Figure 1, the process of swelling/shrinking of the nanogel network under the environmental stimuli action with the controlled release of bioactive substances, is represented.

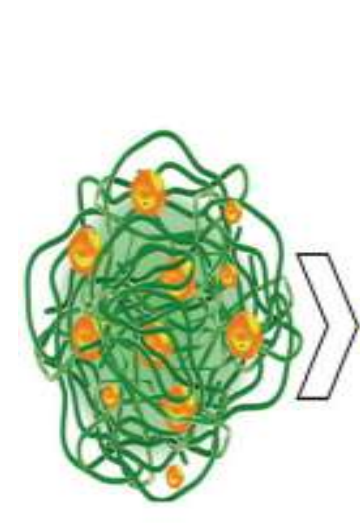

\section{Drug loaded swollen nanogel}

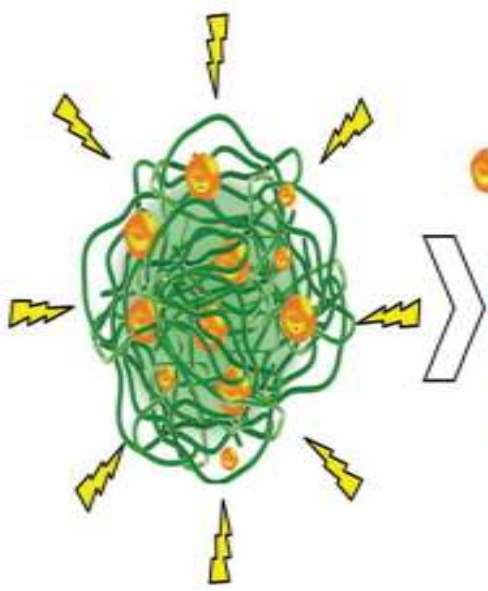

Stimuli environment

\section{Drug release from nanogels}
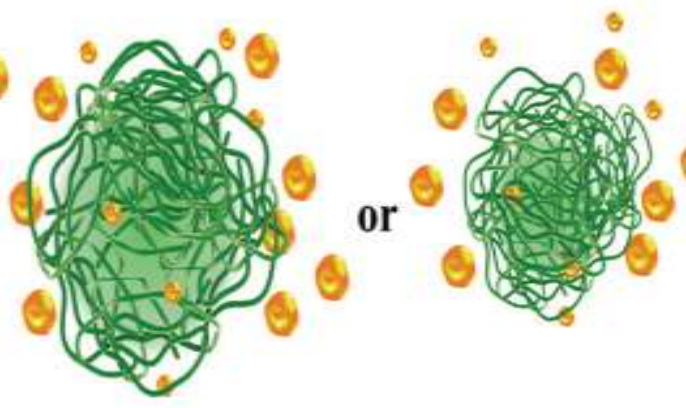

Swelling

Shrinking

Figure 2 : The release of drug from nanogel network(31)

Drug release from nanogel rely upon the interaction of hydrophobic, hydrogen links, complexation and/or coordination of drug molecules with the polymer chain networks. The nanogel network characteristics such as the cross-link density of the gel network, the molecular weight of the polymer, the gel network degradation rate and the interaction of the drugbiomacromolecule with the polymer chains in the gel network control the drug release profile.(32)(22)(31)(33)

In those polymeric nanogels which are thermos responsive the three dimensional cross linked structures allow water molecules to interact with hydrophilic part of the polymer segment aiding it to swell while keeping the original structure intact. This property is embodied near the lower critical solution temperature (LCST) when it turns hydrophobic and removes the water content. As a repercussion, the size of the nanogel particles reduced and the active or therapeutic agent is released via temperature triggered stimulus. (34)(35)

By internal crosslinking modulation of the nanogel network, the drug release can be controlled in response to a stimulus, such as the change in the physiological fluids under disease circumstances (31). Drugs encapsulated through non-covalent links can be released from the delivery vehicle that reacts to stimuli by a physical change in structure. 
The nanogels containing $\mathrm{pH}$-dependent hydrophobic/hydrophilic repeating units or networks are considered to be better drug delivery carriers. These nanogels having ionizable repeating functional groups can absorb positively charged drugs at alkaline $\mathrm{pH}$ through electrostatic attractions and can release them in acidic $\mathrm{pH}$. In the same way, nanogels can absorb biomolecules with low polarity in acidic $\mathrm{pH}$ when the core of nanogels is relatively hydrophobic and can release them in neutral $\mathrm{pH}$ where nanogels become more hydrophilic. They change their swelling or particles size with respect to $\mathrm{pH} .(36)(37)(38)(39)(40)$

\section{Types of nanogel}

The nanogels can be categorized in two ways:

The responsiveness of nanogel

- The kind of propinquity in the network chain of gel structure. Responsive nature of nanogel can further divided into three subtypes:

- stimuli responsive nanogels are vulnerable to environmental changes like temperature, $\mathrm{pH}$, ionic strength and magnetic field. These nanogels swells or shrinks in any one of these varying environmental conditions.

- Multi responsive nanogels reverberate to more than one environmental condition.

- Non responsive nanogels bulged out due to effortless absorbing of water

Polymeric nanogels are further divided into two subtypes:

- Physically Cross-Linked Nanogels

- Chemically cross linked Nanogels

\section{Physically cross linked nanogel}

Hybrid nanogels are those gels in which the nanogel particles are diffused in organic or in organic matrix. Various studies have shown that nanogel synthesis occur by aggregation of polymer amphiphiles for example pullulan-poly(N-isopropylacrylamid) (PNIPAM) and hydrophobizedpullulan nanogel.(41).Pullulan is having extensive worthiness such as it is chemically modifiable to numerous derivatives to emancipate the amphilic property, non-lethal, non carcinogenic, non destructive, non mutagenic, ecological, biocompatible, compatibility with blood is more, binds strongly to asialoglycoprotein receptor and is internalized via receptormediated endocytosis. (42)(43). These hybrid nanogels are capable of delivering drugs more effectively.

\section{Chemically Cross-Linked nanogel}


They consist of permanent chemical linkages i.e. Covalent bonds over the entire network of the gel. The characteristics of cross-linked model rely upon the chemical linkages and functionality groups which are present in the networkof gel. Chemically crosslinked hydrogels are synthesized by chain growth polymerization, addition and condensation polymerization and gamma and electron beam polymerization.

Table 3 : Tabular representation of various types of nanogels(44)

\begin{tabular}{|c|c|c|c|}
\hline S.No & Type of nanogel & $\begin{array}{l}\text { Network } \\
\text { structure }\end{array}$ & Example \\
\hline 1 & Simple nanogel & $\begin{array}{l}\text { a) Cross-linked } \\
\text { b)Semi- } \\
\text { interpenetrating } \\
\text { polymer(semi-IPN) } \\
\text { c)Self-assembled }\end{array}$ & $\begin{array}{l}\text { cholesterol-bearing pullulan } \\
\text { (CHP) nanogel, } \\
\text { Quantum dot nanogel, } \\
\text { Artificial chaperone cholesterol enzymatically } \\
\text { synthesized glycogen (CHSEG) nanogel }\end{array}$ \\
\hline 2 & Hollow nanogel & $\begin{array}{l}\text { Interpenetrating } \\
\text { polymer }\end{array}$ & Stimuli sensitive/responsive nanogel \\
\hline 3 & Core nanogel & Cross linked & Stimuli sensitive/responsive nanogel \\
\hline 4 & Hairy nanogel & Cross linked & Stimuli responsive nanogel \\
\hline 5 & $\begin{array}{l}\text { Multilayer } \\
\text { nanogel }\end{array}$ & Cross linked & Stimuli sensitive/responsive nanogel \\
\hline \multirow[t]{2}{*}{6} & $\begin{array}{l}\text { Functionalized } \\
\text { nanogel }\end{array}$ & Cross linked & $\begin{array}{l}\text { Polyethyleneglycol-b-poly (methacrylic acid) } \\
\text { [PEGb- }\end{array}$ \\
\hline & & & $\begin{array}{l}\text { PMA] with PEG terminal aldehyde } \\
\text { functionality }\end{array}$ \\
\hline
\end{tabular}

\section{Techniques for synthesis}

For the synthesis of nanogel there are number of techniques available and a brief overview of such techniques is given as follows.

\section{(A) Polymerization of monomers in a homogeneous phase or in a microscale or nanoscale heterogeneous environment}

This technique employ the preparation of a colloidal suspension of the polymer by using homogenous nucleation of water soluble polymers and this suspension is than used to synthesize stable nanogels .

For the preparation of smaller particle size nanogel ionic surfactant is incorporated which also enhance the colloidal stability of the preparation. If the amount of surfactant decreases the size of the nanogel formulation increases gradually.(45)

Another method which can be employed is the monomer polymerization by inverse microemulsion (w/o) method with the addition of cross-linkers to produce a stabilized nano network. 
For nanogel synthesis further inverse microemulsion method is also used in which atom transfer radical polymerization (ATRP) is used to synthesize stable cross-linked nanogels (46). A lot of disulfide cross linkers were adopted to synthesize nanogels that are stable in extracellular environment and provide easy release of the drug.

\section{(B) Physical self-assembly of interactive polymers}

Nanogels are indited by employing the physical self-assembled polymers method with amphiphilic polymers, in which the reciprocal action in between the drug and solvent takes place by the Van der Waals' interaction, hydrogen bonding, etc. Micro and macromolecules are entrapped within the nanogels' structure during self-assembly.(12). The particle size of nanogel is controlled in this method by accurate concentration of polymers and varying environmental circumstances such as, $\mathrm{pH}$, temperature, ionic strength.

The preparation of self assembled nanogels also done by employing varying concentrations of two polymers those who are much stable and satisfactory for the long term storage. For the synthesis of nanogel by self associating co polymerization method amphiphilic block co polymers ie. Hydrophobic and hydrophilic polymers are widely availed.(44)

\section{(C) Cross-linking of preformed polymers}

For the preparation of large particle size nanogel this technique is employed. For polynucleotide delivery cross linked cationic nanogel can be used. In the method of cross linking polymerization, nanogel can be prepared by solvent evaporation of an oil in water emulsion whereas PEG can bein conjugation to a branched polyethyleneamine in aqueous system.(12)

Functional nanogels with huge pore sizes for the delivery of the active constituent can be produced by the method of covalent cross linking of preformed polymer chains. Those nanogels which are formulated using chemical cross linking method have varying degree of shapes such as sphere, rod and toroids.

This cross linking technique is used to control the particle size, shape, surface characteristics and composition as well. When vinyl monomers are present than the method of copolymerization can be carried out.

\section{(D) Emulsion photopolymerization process}

In the emulsion photopolymerization process, UV method is used to prepare dextran nanogel, where dextran hydroxyethyl methacrylate is emulsified with ABIL EM 90 as emulgent in mineral oil, the product is obtained in (1:1) acetone: hexane solution. (44). Photosensitizer is used for the breakage of endosomal membranes to release of genes in the cytoplasm and nuclease.(12) 


\section{(E) Novel photochemical approach}

Photochemical approach is used to produce $N$-(2-aminoethyl) methylacrylamide and $N, N^{\prime}$ methylene bis-acrylamide- coated ferric oxide nanoparticles nanogels, developed by magnetic resonance imaging (MRI), where nanogels are treated with UV radiation at $388 \mathrm{~nm}$ for 10 $\min .(47)$

\section{(F) Novel pullulan chemistry modification}

A mixture of cholesterol isocynate in dimethyl sulfoxide and pyridine was used to synthesize cholesterol-based pullulan (CHP) nanogel. CHP is composed of pullulan backbone and cholesterol branches. The CHP molecules self aggregate to form mono-dispersed stable nanogels through the association of hydrophobic groups that provide physical crosslinking .Pullulan is substituted by 1.4 cholesterol moieties per 100 anhydrous glucoside units. All preparations synthesized by the CHP method should be freeze-dried. The CHP method has been especially known to act as good protein carrier nanogels formulation . Michael addition reaction was used to modify CHP method where the acrylate group and the thiol group were substituted by polyethylene glycol(12)

\section{(G) Chemical modifications}

Chemical modification of polymers supports release of drugs from the nanogels formulation. Few examples are as follows: Modified $\mathrm{pH}$-sensitive hydroxypropylcellulose polyacrylic acid nanogels are used for bio-imaging of cells by sensing the physicochemical environment. Acetylation of chondroitinsulfate will increase the release of doxorubicin for 3 weeks in the HeLa cells, which can be used in cancer treatment.(48)

\section{Utilization of nanogel in cosmeceuticals and various other fields}

Various aspects of nanogel have been studied and from the literature it was found that nanogel has found its application in various fields. Some of those areas in which nanogel can be successfully used are drug delivery for example in cancer treatment, in ophthalmology, gene therapy, in various disorders such as gastro intestinal disorders ,in diabetes, bone regeneration, controlled delivery system, targeted delivery systems etc. Nanogels are widely used in diagnostics and imaging purposes as well. (44)

In cosmeceuticals the development of various formulations in form of nanogel is enhancing as nanogels provide promising active constituent delivery to the skin. In new era nanotechnology especially nanogels were widely accepted by the market due to incorporation of active ingredients for anti aging, wrinkles, moisturization etc.

\section{Anti aging}


This section of cosmeceutical products depicts the maximum growth as people want more products as an alternatives to skin replacement surgeries or laser techniques. Also the awareness for looking more appealing and youthful enhances the nanogel based anti aging cosmeceuticals. Few ingredients which are used globally for anti ageing therapy are as follows:

\section{Hydroxy acids:}

Encapsulated nano hydroxyacids are more prevalent in cosmetic industry. They have an average diameter of $200-300 \mathrm{~nm}$ and they are produced to enhance the capability of hydroxy acids. Actives in these formulations are glycolic acid, lactic acid, citric acid, liquid extract and oat oil. It acts by decreasing the thickness of stratum corneum the upper layer of skin and it enhance the reduction of adjoining of corneocytes.

\section{Retinoids:}

They are widely applied in the removal of wrinkles and fine lines from the face, neck and body. These class of compounds are the derivative of vitamin A. These retinoids formulations are also employed in skin cancers, inflammatory skin problems, photo aging, psoriasis etc. Nanotechnology based tretinoin gels have shown excellent results in treating acne and acne scars. Studies have shown that liposomes. Solid lipid nanoparticles, nanogels, microemulsions, have shown an enhance delivery of anti acne actives when compared to the conventional topical formulations like creams, lotions etc.

Hyalouronic acids: it is a nonsulphated glycosaminoglycan made up of polymeric disaccharides of D-glucuronic acid and N-acetyl-D-glucosamine. It has been observed that amount of hyalouronic acid decreases during the process of aging. Soft tissue dermal fillers consist of hyalouronic acid nanoparticle have been researched to abolish aging changes in skin affirmation and appearance.

\section{Moisturizers}

They are those preparations which make the skin more hydrated as well as preserve the moisture content of the skin. Nowadays hydrogel based ultramoisturizing(HUMC) formulations have been developed for the hydration of skin. Conventional moisturizers consist of lotions creams oils etc but novel technology provide nanogel based moisturizerwith urea, carbopol, grapeseeed oil etc which provides an excellent hydration as well as enhance permeation of actives into the skin.

\section{Sunscreens}

Sunscreens are widely used globally to prevent the skin from the harmful UV rays. These UV rays can even damage the DNA and causes mutation which leads to skin cancer. Chemical agents are used in sunscreen preparation such zinc oxide, titanium dioxide etc. The zinc oxide and 
titanium dioxide nanoparticles are transparent and provide wide range of protection from UVA and UVB rays.

\section{Hair care}

Apart from skin hair is also the most appealing and promising characteristics of the appearance of an individual. Nanomaterials used as delivery system for bioactive materials to the hair follicle to enhance hair growth and reduction in hair fall. There are wide variety of products such as shampoos, conditioners which contain nano materials as active ingredient. These nanomaterial prevent excessive hair drying and dullness while grooming. Chitin and zinc nanofibres reduces the sebum production in hair and thus reduced amount of flakes on the scalp, we can also say that they act as anti dandruff agents.

The applicability of nanogels in various cosmeceutical products have been depicted in the table along with other details.(44)

Table 4: Application of nanogel based products in cosmeceuticals

\begin{tabular}{|c|c|c|c|}
\hline S.No. & Product name & Manufacturer & Product usage \\
\hline 1 & $\begin{array}{l}\text { Nano gel gold } \\
\text { and Nano gel } \\
\text { silver }\end{array}$ & $\begin{array}{l}\text { Nano medic } \\
\text { series }\end{array}$ & $\begin{array}{l}\text { It will cleanse the skin deeply with moisturisation } \\
\text { effect, also reduces the signs of aging and make } \\
\text { skin more supple and tighten }\end{array}$ \\
\hline 2 & CTx3 Gel & Carifree & $\begin{array}{l}\text { Nano HA - Optimal levels of nanoparticle } \\
\text { hydroxyapatite is present as a protective agent. It } \\
\text { prevents dental caries. }\end{array}$ \\
\hline 3 & Nanotrim gel & Sane care & $\begin{array}{l}\text { It contains Nano LPD extract which is made up of } \\
\text { natural active ingredients of Laminaria, Caffein } \\
\text { and Ivy and help in reducing fat . also provide } \\
\text { moisturisation and anti ageing effect }\end{array}$ \\
\hline 4 & $\begin{array}{l}\text { NBF Gingival } \\
\text { gel }\end{array}$ & $\begin{array}{l}\text { Sungwon } \\
\text { pharmaceuticals }\end{array}$ & $\begin{array}{l}\text { NBF GEL is a new multifunctional gel based } \\
\text { nanotechnology to protect the gum and oral } \\
\text { cavity. Created using the revolutionary } \\
\text { Nano-Bio Fusion Technology. }\end{array}$ \\
\hline 5 & $\begin{array}{l}\text { Skin perfect } \\
\text { brightening } \\
\text { nanogel }\end{array}$ & $\begin{array}{l}\text { MDD } \\
\text { cosmeceuticals }\end{array}$ & $\begin{array}{l}\text { This nanogel make skin look more radiant healthy } \\
\text { and the pearl essence makes skin more glowing } \\
\text { with even skin tone. }\end{array}$ \\
\hline 6 & $\begin{array}{l}\text { Augen nanogel- } \\
\text { eye care gel }\end{array}$ & Dr. RA Eckstein & $\begin{array}{l}\text { Nourishing, anti-aging eye care serum for all skin } \\
\text { types. }\end{array}$ \\
\hline 7 & $\begin{array}{l}\text { Nioret } 0.025 \% \\
\text { Nanogel }\end{array}$ & ZydusCadilla & $\begin{array}{l}\text { It is a derivative of vitamin } A \text { and is used for the } \\
\text { treatment of acne and reduce wrinkles of the face. }\end{array}$ \\
\hline 8 & $\begin{array}{l}\text { Pro collagen } \\
\text { nanogel }\end{array}$ & Revivagenix & $\begin{array}{l}\text { It is a perfect solution for anti ageing and } \\
\text { rejuvenates skin. It causes reaffirmation of the } \\
\text { skin. }\end{array}$ \\
\hline 9 & $\begin{array}{l}\text { Suntrap } \\
\text { nanogel }\end{array}$ & $\begin{array}{l}\text { Velite } \\
\text { pharmaceuticals }\end{array}$ & $\begin{array}{l}\text { It comes with SPF } 30+\text { and protects the skin } \\
\text { against harmful UVA AND UVB RAYS }\end{array}$ \\
\hline 10 & $\begin{array}{l}\text { Zyclin } \\
\text { Gel }\end{array}$ & Zydus Cadilla & $\begin{array}{l}\text { It contains clindamycin which acts as an anti acne } \\
\text { ingredient. }\end{array}$ \\
\hline
\end{tabular}




\begin{tabular}{llll}
\hline 11 & Silver gel & $\begin{array}{l}\text { American biotech } \\
\text { labs }\end{array}$ & $\begin{array}{l}\text { It can be used topically for the treatment of } \\
\text { wounds, laceration and skin abrasion }\end{array}$ \\
\hline
\end{tabular}

Table 5 : Application of nanogel in various other fields.(49)

\begin{tabular}{|c|c|c|c|}
\hline S.No & $\begin{array}{l}\text { Area of use / } \\
\text { disease }\end{array}$ & Nanogel used & Explanation \\
\hline 1 & $\begin{array}{l}\text { Bone } \\
\text { regeneration }\end{array}$ & lithium nanogels & $\begin{array}{l}\text { These nanogels are prepared by micro } \\
\text { emulsion polymerization technique }\end{array}$ \\
\hline 2 & $\begin{array}{l}\text { Pathogen } \\
\text { activity }\end{array}$ & $\begin{array}{l}\text { Dextran nanogel loaded with } \\
\text { zinc nitrate }\end{array}$ & $\begin{array}{l}\text { These nanogels are prepared by mini } \\
\text { emulsion method and they have action } \\
\text { against strains of S.aureus bacteria }\end{array}$ \\
\hline 3 & $\begin{array}{l}\text { Autoimmune } \\
\text { disorders }\end{array}$ & $\begin{array}{l}\text { Mycophenolic acid nanogel } \\
\text { complexed with non } \\
\text { methylated beta cyclodextrin }\end{array}$ & $\begin{array}{l}\text { The nanogel system is exposed to uv } \\
\text { rays to provide a stable gel mixture }\end{array}$ \\
\hline 4 & Diabetes & $\begin{array}{l}\text { Injectable nanogel network } \\
\text { which is sensitive to glucose } \\
\text { levels }\end{array}$ & $\begin{array}{l}\text { Nanogel network carries insulin which } \\
\text { is required for conversion of glucose } \\
\text { into gluconic acid }\end{array}$ \\
\hline 5 & $\begin{array}{l}\text { Cancer } \\
\text { treatment }\end{array}$ & $\begin{array}{l}\mathrm{pH} \text {, thermal and stimuli } \\
\text { sensitive nanogel of } \\
\text { doxorubicin, cisplatin } \\
\text { choleseterol bearing pullulan } \\
\text { nanogel }\end{array}$ & $\begin{array}{l}\mathrm{pH} \text { thermal dual responsive } \\
\text { nanogel mainly used for } \\
\text { breast cancer therapy }\end{array}$ \\
\hline
\end{tabular}

\section{CONCLUSION}

We have seen various aspects of nanogel formulations including its synthesis, delivery and utilization especially in cosmeceuticals. It is that area of nanotechnology which is to be more explored and developed to provide betterment in delivery of active cosmeceutical ingredients to skin. Nanogels are one of the favourable area for the global market profitability, so approaches are required to design formulations based on nanotechnology. Furthermore, efforts should be driven towards the more detailed analysis technique of nanogel formulations. The future potential lies in developing biodegradable and bio compatible nanogels for cosmeceuticals. Nanogel are propitious as they have many additional benefits when compared to the conventional or age old topical skin care, hair care products. Also, the need of the hour is to design indefectible cosmeceutical products as nowadays not only women but men have also started paying attention towards the anti aging. Anti wrinkle, anti acne, hair growth and other grooming commodities.

\section{REFERENCES}

1. Raj S, Jose S, Sumod US, Sabitha M. Nanotechnology in cosmetics: Opportunities and challenges. J Pharm Bioallied Sci. 2012;4(3):186-93. 
2. Nanjwade BK. Development of Cosmeceuticals. World J Pharm Pharm Sci. 2017;6(4):643-91.

3. Rana K, Rana B, Bala K. The Emerging Trends of Nanoscience in Cosmetics. 2017;05(08):6810-6. Available

from: http://ijsae.in/index.php/ijsae/article/viewFile/234/149

4. Mu L, Sprando RL. Application of nanotechnology in cosmetics. Pharm Res. 2010;27(8):1746-9.

5. Soni K s., Desale S s., Bronich T k. HHS Public Access. J Control Release. 2016;240:109-26.

6. Torchilin VP. Multifunctional, stimuli-sensitive nanoparticulate systems for drug delivery. Nat Rev Drug Discov [Internet]. 2014;13(11):813-27. Available from: http://dx.doi.org/10.1038/nrd4333

7. Motornov M, Roiter Y, Tokarev I, Minko S. Stimuli-responsive nanoparticles, nanogels and capsules for integrated multifunctional intelligent systems. Prog Polym Sci. 2010;35(1-2):174-211.

8. Mura S, Nicolas J, Couvreur P. Stimuli-responsive nanocarriers for drug delivery. Nat Mater [Internet]. 2013;12(11):991-1003. Available from: http://dx.doi.org/10.1038/nmat3776

9. Oh JK, Drumright R, Siegwart DJ, Matyjaszewski K. The development of microgels/nanogels for drug delivery applications. Prog Polym Sci. 2008;33(4):448-77.

10. Zha L, Banik B, Alexis F. Stimulus responsive nanogels for drug delivery. Soft Matter. 2011;7(13):5908-16.

11. Kabanov A V., Vinogradov S V. Nanogels as pharmaceutical carriers: Finite networks of infinite capabilities. Angew Chemie - Int Ed. 2009;48(30):5418-29.

12. Neamtu I, Rusu AG, Diaconu A, Nita LE, Chiriac AP. Basic concepts and recent advances in nanogels as carriers for medical applications. Drug Deliv. 2017;24(1):53957.

13. Nanobiomaterials S, Rolland JP, Maynor BW, Euliss LE, Exner AE, Denison GM, et al. Direct Fabrication and Harvesting of Monodisperse,. J Am Chem Ociety. 2005;127(28):10096-100.

14. Kersey FR, Merkel TJ, Perry JL, Napier ME, Desimone JM. Effect of aspect ratio and deformability on nanoparticle extravasation through nanopores. Langmuir. 2012;28(23):8773-81. 
15. Malmsten M. Soft Matter's Top Ten Articles Top Ten Articles. 2006;611846.

16. Napier ME, DeSimone JM. Nanoparticle drug delivery platform. Polym Rev. 2007;47(3):321-7.

17. McAllister K, Sazani P, Adam M, Cho MJ, Rubinstein M, Samulski RJ, et al. Polymeric nanogels produced via inverse microemulsion polymerization as potential gene and antisense delivery agents. J Am Chem Soc. 2002;124(51):15198-207.

18. Wiechers JW, Musee N. Engineered inorganic nanoparticles and cosmetics: Facts, issues, knowledge gaps and challenges. J Biomed Nanotechnol. 2010;6(5):408-31.

19. Garg T, Goyal AK. Biomaterial-based scaffolds-current status and future directions. Expert Opin Drug Deliv. 2014;11(5):776-89.

20. Moya-Ortega MD, Alvarez-Lorenzo C, Concheiro A, Loftsson T. Cyclodextrin-based nanogels for pharmaceutical and biomedical applications. Int J Pharm. 2012;428(12):152-63.

21. Sawada SI, Sasaki Y, Nomura Y, Akiyoshi K. Cyclodextrin-responsive nanogel as an artificial chaperone for horseradish peroxidase. Colloid Polym Sci. 2011;289(5-6):68591.

22. Vinogradov S V., Bronich TK, Kabanov A V. Nanosized cationic hydrogels for drug delivery: Preparation, properties and interactions with cells. Adv Drug Deliv Rev. 2002;54(1):135-47.

23. Kabanov A V., Batrakova E V., Alakhov VY. Pluronic ${ }^{\circledR}$ block copolymers as novel polymer therapeutics for drug and gene delivery. J Control Release. 2002;82(2-3):189212.

24. Fu AS, von Recum HA. Affinity-Based Drug Delivery. Eng Polym Syst Improv Drug Deliv. 2013;9781118098:429-52.

25. Morie A, Garg T, Goyal AK, Rath G. Nanofibers as novel drug carrier - An overview. Artif Cells, Nanomedicine Biotechnol. 2016;44(1):135-43.

26. Hamidi M, Rostamizadeh K, Shahbazi MA. Hydrogel Nanoparticles in Drug Delivery. Intell Nanomater Process Prop Appl. 2012;60:583-624.

27. Ganesh VA, Baji A, Ramakrishna S. Smart functional polymers - A new route towards creating a sustainable environment. RSC Adv [Internet]. 2014;4(95):53352-64. Available from: http://dx.doi.org/10.1039/C4RA10631H

28. Crucho CIC. Stimuli-responsive polymeric nanoparticles for nanomedicine. ChemMedChem. 2015;10(1):24-38. 
29. Wang Y, Luo Y, Zhao Q, Wang Z, Xu Z, Jia X. An Enzyme-Responsive Nanogel Carrier Based on PAMAM Dendrimers for Drug Delivery. ACS Appl Mater Interfaces. 2016;8(31):19899-906.

30. Zhou X, Lin A, Yuan X, Li H, Ma D, Xue W. Glucose-sensitive and blood-compatible nanogels for insulin controlled release. J Appl Polym Sci. 2016;133(24):2-9.

31. Yallapu MM, Reddy MK, Labhasetwar V. Nanogels: Chemistry to Drug Delivery. Biomed Appl Nanotechnol. 2007;131-71.

32. Hoffman AS, Stayton PS, Press O, Murthy N, Lackey CA, Cheung C, et al. Design of "smart" Polymers that can direct intracellular drug delivery. Polym Adv Technol. 2002;13(10-12):992-9.

33. Jaiswal MK, Pradhan A, Banerjee R, Bahadur D. Dual pH and temperature stimuliresponsive magnetic nanohydrogels for thermo-chemotherapy. J Nanosci Nanotechnol. 2014;14(6):4082-9.

34. Satarkar NS, Hilt JZ. Magnetic hydrogel nanocomposites for remote controlled pulsatile drug release. J Control Release. 2008;130(3):246-51.

35. Demirel G, Rzaev Z, Patir S, Pişkin E. Poly(N-isopropylacrylamide) layers on silicon wafers as smart DNA-sensor platforms. J Nanosci Nanotechnol. 2009;9(3):1865-71.

36. Das M, Mardyani S, Chan WCW, Kumacheva E. Biofunctionalized pH-responsive microgels for cancer cell targeting: Rational design. Adv Mater. 2006;18(1):80-3.

37. Dupin D, Fujii S, Armes SP, Reeve P, Baxter SM. Efficient synthesis of sterically stabilized pH-responsive microgels of controllable particle diameter by emulsion polymerization. Langmuir. 2006;22(7):3381-7.

38. Pich A, Tessier A, Boyko V, Lu Y, Adler HJP. Synthesis and characterization of poly(vinylcaprolactam)-based microgels exhibiting temperature and $\mathrm{pH}$-sensitive properties. Macromolecules. 2006;39(22):7701-7.

39. Pujana MA, Pérez-Álvarez L, Iturbe LCC, Katime I. Water soluble folate-chitosan nanogels crosslinked by genipin. Carbohydr Polym [Internet]. 2014;101(1):113-20. Available from: http://dx.doi.org/10.1016/j.carbpol.2013.09.014

40. Zeng Z, She Y, Peng Z, Wei J, He X. Enzyme-mediated in situ formation of pH-sensitive nanogels for proteins delivery. RSC Adv [Internet]. 2016;6(10):8032-42. Available from: http://dx.doi.org/10.1039/C5RA25133H

41. Sultana F, Manirujjaman, Imran-Ul-Haque, Arafat M, Sharmin S. An overview of nanogel drug delivery system. J Appl Pharm Sci. 2013;3(8 SUPPL):95-105. 
42. Ferreira SA, Coutinho PJG, Gama FM. Synthesis and characterization of self-assembled nanogels made of pullulan. Materials (Basel). 2010;4(4):601-20.

43. Zarekar NS, Lingayat VJ, Pande V V. Nanogel as a Novel Platform for Smart Drug Delivery System. Nanosci Nanotechnol Res Vol 4, 2017, Pages 25-31 [Internet]. 2017;4(1):25-31. Available from: http://pubs.sciepub.com/nnr/4/1/4/

44. Sharma A, Garg T, Aman A, Panchal K, Sharma R, Kumar S, et al. Nanogel - An advanced drug delivery tool: Current and future. Artif Cells, Nanomedicine Biotechnol. 2016;44(1):165-77.

45. Nayak S, Andrew Lyon L. Soft nanotechnology with soft nanoparticles. Angew Chemie Int Ed. 2005;44(47):7686-708.

46. Oh JK, Tang C, Gao H, Tsarevsky N V., Matyjaszewski K. Inverse miniemulsion ATRP: A new method for synthesis and functionalization of well-defined water-soluble/crosslinked polymeric particles. J Am Chem Soc. 2006;128(16):5578-84.

47. Gong Y, Kakihara Y, Krogan N, Greenblatt J, Emili A, Zhang Z, et al. An atlas of chaperone-protein interactions in Saccharomyces cerevisiae: Implications to protein folding pathways in the cell. Mol Syst Biol [Internet]. 2009;5(275):1-14. Available from: http://dx.doi.org/10.1038/msb.2009.26

48. Chacko RT, Ventura J, Zhuang J, Thayumanavan S. Polymer nanogels: A versatile nanoscopic drug delivery platform. Adv Drug Deliv Rev [Internet]. 2012;64(9):836-51. Available from: http://dx.doi.org/10.1016/j.addr.2012.02.002

49. Yadav HK, Halabi A, Alsalloum NA. Nanogels as Novel Drug Delivery Systems-A Review. J Pharm Pharm Res [Internet]. 2017;1:5. Available from: http://www.imedpub.com/ 